sense of Walcott, bridging the time between the Pre-Cambrian and the Palæozoic.

During much of Palæozoic time and later, the Australian continent is pictured as bounded east and west by geosynclines.

In particular, the attention of the reader is arrested by the account of the great tectonic depression known (and so named by Schuchert) as the Tasman geosyncline, covering at various times much of eastern Australia and Tasmania. The synthesis of events that gave growth and change to this majestic structure forms a central theme in the discussions of the Palæozoic System, and the detailed account of its structure, its repeated orogenies and synchronous or subsequent granitic epochs form one of the most fascinating sections of the book.

The magnificent vista thus skilfully revealed will give added stimulus to the prosecution of major groups of researches, providing, for decades to come, lines of investigation for workers in all departments of the science.

In the long geological history of Australia so clearly depicted, it is pleasing to find that measured emphasis is given to the place of vulcanism and plutonic igneous activity, with an attempted assessment of their role in the stratigraphic and tectonic record. Knowledge of the vulcanicity is perhaps most detailed among the Tertiary lava floods of eastern Australia, where petrological investigation has been more intensively carried forward. The book is enriched by an up-to-date chapter on Australian New Guinea prepared by officers of the Australasian Petroleum Co. One of the more interesting disclosures emerging from recent study of this region, and here recounted, is the refutation of the long current interpretation of the occurrence of over-thrusts of Alpine type among the younger folded rocks; on the contrary, the mountain-building movements are now recognized as being primarily vertical rather than horizontal.

The section on physiography, a work of 141 pages in the second volume, provides an exemplary account of the main features of the geomorphology of the continent of Australia. The larger section of the volume, however, is devoted to economic geology, commencing with a general account of the distribution of ores in space and time and their close relation to the epochs of plutonic intrusion.

Thereafter each of the chief metals is described in chapters divided by States. Important sections deal with coal, lignite and oil shale, and the descriptions conclude with a survey of artesian basins which cover in the aggregate upwards of one-third of the area of Australia, the largest in regions of low rainfall. The results of the prolonged study of these basins, the problems of their stratigraphy, structure and chief aquifers, and of the flow and salinity of their waters, are very completely set out with copious reference to the extensive researches devoted to this field. Many other fascinating topics, which in the limits of a short review it is impossible adequately to consider, are lucidly expounded in this monumental treatise.

Here will be found the discussion of such diverse subjects as the evidence for no less than five ancient glaciations, three of them of major extent and duration ; the nature of the correspondence between recorded diastrophisms and those of extra-Australian regions; the rise and extinction of the distinctive land flora of the Carboniferous and the controversial problem of the Permian boundary ; the status of the Papuan geosyncline; the disruption of the Australasian continent; and the antiquity of man.
The topics are legion, and it would appear that no significant study devoted to the regional geology has escaped summary. The book without doubt will endure as the chief reference work on Australian geology for many years. In the concluding sentence of the introduction the study is described-and well described-as at once a stocktaking and an interpretation. That it also forms a secure foundation on which the student of to-morrow may build Dr. Browne may be emphatically assured, and can proudly so claim. The impressive work marks, indeed, a vantage point in the history of advance in regional geology with which the names of David and Browne will always be associated.

C. E. TrLLEy

\section{THE TEACHING OF COLLOID CHEMISTRY}

Kurzes Lehrbuch der Kolloidchemie

Von Dr. B. Jirgensons und Dr. M. Straumanis. Pp. viii + 282. (Berlin, Göttingen und Heidelberg : Springer-Verlag, 1949.) 21.60 D. marks.

THE importance of a sound knowledge of colloid science to the chemical technologist has resulted in more attention being paid to this subject in university courses in recent years. A number of excellent monographs and larger volumes aimed mainly at the already trained worker exist, but there are few treatments written frankly for the student. This compact work by Drs. B. Jirgensons and M. Straumanis is therefore welcome. It is unpretentious : it is a university text-book and nothing more, but it is a good one. The authors have known what to leave out as well as what to put in. The student is guided logically through what can be pedagogically an awkward subject, and the introduction to modern physical techniques comes early. This is a good point, as it is unwise to overload the new student with all the classical burden; it is better to present him early on with a sound framework into which he can fit further facts and observations as he comes across them.

The descriptions of experimental techniques are of just the right standard: the main features and underlying theory are given, and the reader is guided to the essential literature. In a second edition, the opportunity might be taken to include a short section on the low-angle X-ray scattering method for particle-size determination in the 100-A. range. At the same time, the section on the X-ray linebroadening method could be slightly amplified to cover the intensive discussions on this subject which occurred in Great Britain during the war years.

As might be expected, the book to some extent reflects the barrier of the war period. This could easily be remedied in a new edition which, while broadened to embrace recent American and British advances, should not lose the present book's high quality of presentation. In my opinion, this short book of some 280 pages would be well worth trans. lating into English for the benefit of the many students who find difficulty in reading German. It does not compete with recent larger works which can give a much fuller and more thorough treatment than is attempted by Jirgensons and Straumanis. Its attractive features are its succinctness, its wise selection of material and the exceptional clarity of treatment.
D. P. RIMEY 